\title{
ANALISIS PROBLEMATIKA PEMBELAJARAN TEMATIK TERHADAP PESERTA DIDIK KELAS IV DI SD N KADIPIRO NO. 144 SURAKARTA TAHUN PELAJARAN 2018/2019
}

\author{
Ani Mandasari ${ }^{1}$, Sri Hartini ${ }^{2}$, Mukhlis Mustofa ${ }^{3}$ \\ Universitas Slamet Riyadi \\ E-mail: animandasari108@gmail.com
}

\begin{abstract}
The purpose of this study is to analyze the problems that exist in thematic learning, including the cognitive, affective, and psychomotor domains. This research was conducted in January - June at SD N Kadipiro No. 144 Surakarta in class IV students. This type of research is a qualitative descriptive study. The subjects of this study were students of Class IV, and teachers at SD N Kadipiro No. 144 Surakarta. While the method of collecting data in this study is through observation, semi-structured interviews, documentation, and open questionnaires. (1) The observation method is used to be able to observe and know directly the cognitive, affective, and psychomotor aspects of students. (2) The interview method is used to get the information needed. (3) The documentation method is used to find out the school profile, learning tools, data of Class IV students in SD N Kadipiro No. 144 Surakarta, and cognitive problems that arise in thematic learning. (4) The open questionnaire method is used to obtain information from students who have not gotten the author from the results of the interview. The technique of checking the validity of qualitative data is done by using source triangulation and method triangulation. The data in this study were analyzed in the order of data reduction, data presentation, conclusion drawing, and verification. The results of this study are found problems in (1) cognitive domain (knowledge), namely students do not understand the material to the fullest, have not been able to make the core of learning, difficulty in differentiating work that produces goods and services, difficulty in determining characterizations in fiction, there are still who do not like thematic learning, there are still students who have not done the task or test independently, and students who do not enter due to permission or illness have difficulty understanding the material independently. (2) The affective domain (attitude) is found to be a problem, namely an attitude of confidence, activeness, independence, and honesty that still needs to be emphasized again to students. (3) Psychomotor domains (skills), namely the lack of ability of students to draw three-dimensional shapes well, lack of ability to speak in front of the class, making a custom home from stick ice cream firmly, and creativity to make three-dimensional objects from plasticine.
\end{abstract}

Keywords: Thematic Learning, Cognitive Domains, Affective Domains, and Domains Psychomotor.

\begin{abstract}
Abstrak
Tujuan penelitian ini adalah untuk menganalisis problematika yang ada dalam pembelajaran tematik, meliputi ranah kognitif, ranah afektif, dan ranah psikomotorik. Penelitian ini dilaksanakan pada bulan Januari - Juni di SD N Kadipiro No. 144 Surakarta pada peserta didik kelas IV. Jenis penelitian yang digunakan adalah penelitian deskriptif kualitatif. Subjek penelitian ini adalah peserta didik Kelas IV, dan guru di SD N Kadipiro No. 144 Surakarta. Sedangkan metode pengumpulan data pada penelitian ini ialah melalui observasi, wawancara semi terstruktur, dokumentasi, dan angket terbuka. (1) Metode observasi digunakan untuk dapat mengamati dan mengetahui secara langsung aspek kognitif, afektif, dan psikomotorik peserta didik. (2) Metode wawancara digunakan untuk mendapatkan informasi yang dibutuhkan. (3) Metode dokumentasi digunakan untuk mengetahui profil sekolah, perangkat pembelajaran, data peserta didik Kelas IV di SD N Kadipiro No. 144 Surakarta, dan problematika kognitif yang timbul dalam pembelajaran tematik. (4) Metode angket terbuka digunakan untuk mendapatkan informasi dari peserta didik yang penulis belum dapatkan dari hasil wawancara. Teknik pemeriksaan keabsahan data kualitatif dilakukan dengan trianggulasi sumber dan trianggulasi metode. Data pada penelitian ini dianalisis dengan urutan reduksi data, penyajian data, penarikan kesimpulan, dan verifikasi. Hasil penelitian ini adalah ditemukan problematika pada (1) ranah kognitif (pengetahuan) yaitu peserta didik belum memahami materi secara maksimal, belum mampu membuat inti pembelajaran, kesulitan membedakan pekerjaan yang menghasilkan barang dan jasa, kesulitan untuk menentukan penokohan di dalam cerita fiksi, masih ada yang kurang menyukai pembelajaran tematik, masih terdapat peserta didik yang belum mengerjakan tugas atau ulangan secara mandiri, serta peserta didik yang tidak masuk dikarenakan izin atau sakit kesulitan untuk memahami materi secara mandiri. (2) Ranah afektif (sikap) ditemukan problematika yaitu sikap percaya diri, keaktifan, kemandirian, dan kejujuran yang masih perlu ditekankan lagi kepada peserta didik. (3) Ranah psikomotorik (keterampilan) yaitu kurang mampunya peserta didik untuk menggambar bentuk tiga dimensi dengan baik, kurangnya kemampuan berbicara di depan kelas, membuat rumah adat dari stick ice cream dengan kokoh, dan kreatifitas untuk membuat benda berbentuk tiga dimensi dari plastisin.
\end{abstract}

Kata Kunci: Pembelajaran Tematik, Ranah Kognitif, Ranah Afektif, dan Ranah Psikomotorik.

\section{PENDAHULUAN}

Proses pembelajaran selama ini mengesampingkan karakter yang berakhlak

mulia. Padahal karakter dapat menentukan sikap peserta didik untuk menambah ilmu 
pengetahuan. Hal tersebut menjadi salah satu alasan bergantinya KTSP ke Kurikulum 2013 dalam pendidikan Sekolah Dasar yang menerapkan pembelajaran tematik.

Menurut Zainal Aqib (2010: 41) pembelajaran adalah susunan hubungan dari kebutuhan pendidikan, untuk belajar. Sedangkan Tematik atau terpadu merupakan perpaduan beberapa kompetensi dasar beserta indikator yang disatukan sehingga menjadi kesatuan berbentuk tema. "Pembelajaran tematik menggunakan tema untuk dapat mengaitkan beberapa mata pelajaran agar peserta didik mendapatkan pengalaman yang bermakna tanpa mengabaikan penanaman karakter" (Depdiknas dalam Sa'dun Akbar, 2017: 17).

Keluhan yang muncul dalam pelaksanaan pembelajaran Tematik pada Kelas IV di SD N Kadipiro No. 144 Surakarta yaitu peserta didik Kelas IV masih kesukaran dalam menerapkan pembelajaran tematik. Sehingga mereka kurang memperhatikan guru yang mengajar. Peserta didik masih terbawa dengan kurikulum sebelumnya yang memisahkan setiap mata pelajaran. Pemecahan mata pelajaran dalam pembelajaran tematik pun kurang jelas

\section{KAJIAN PUSTAKA}

\section{A. Pembelajaran Tematik}

Pembelajaran tematik merupakan komponen dari pembelajaran yang membiasakan peserta didik untuk aktif mencari, mendapatkan konsep pembelajaran yang sedang dibahas, prinsip keilmuan yang penuh arti, nyata, dan bersumber dari pemikiran setiap peserta didik (Rusman, 2016: 254). Pembelajaran tematik berusaha membuat peserta didik baik secara kelompok ataupun individu menjadi aktif dalam pelaksanaannya agar lebih memahami materi berdasarkan konsepnya. Sebab, konsep pembelajaran merupakan dasar materi. Sehingga, adanya pemahaman terhadap konsep berarti peserta didik dapat menyimpan ingatannya terhadap materi yang dipelajari.

\section{B. Keunggulan dan Kelemahan Pembelajaran Tematik}

\section{Keunggulan Pembelajaran Tematik}

karena memang di dalam kurikulum ini memadukan berbagai pelajaran, banyaknya penilaian yang harus diselesaikan oleh guru dengan cukup menghabiskan waktu, dan banyaknya pekerjaan sekolah yang harus diselesaikan oleh peserta didik.

Berdasarkan deskripsi yang diuraikan di atas, maka penulis melakukan penelitian dengan judul "Analisis Problematika Pembelajaran Tematik Terhadap Peserta Didik Kelas IV di SD N Kadipiro No. 144 Surakarta Tahun Pelajaran 2018/2019".

Penelitian ini mempunyai tujuan untuk menganalisis problematika yang ada dalam pembelajaran tematik di SD N Kadipiro No. 144 Surakarta pada tahun pelajaran 2018/2019, meliputi: Ranah kognitif (pengetahuan dan hasil belajar peserta didik pada pembelajaran tematik), Ranah afektif (sikap yang ditimbulkan pada keberagaman budaya, nilai moral dongeng yang diterapkan, dan sikap peduli terhadap tanah air), dan Ranah psikomotorik (keterampilan yang dimiliki pembuatan karya, tari, PJOK, dan menggambar) pada peserta didik kelas IV, pada Tema 8 "Daerah Tempat Tinggalku".

Menurut Abd. Kadir dan Hanun Asrohah (2015: 26) keunggulan pembelajaran tematik, yaitu:

a. Menghindari tumpang tindih konsep pembelajaran antar bab.

b. Alokasi waktu pembelajaran lebih hemat dan efisien.

c. Peserta didik mampu melihat kaitan-kaitan materi yang bermakna.

d. Pembelajaran menjadi holistik dan menyeluruh.

e. Keterkaitan antara satu mata pelajaran dengan yang lainnya akan mnguatkan konsep yang telah dikuasai peserta didik.

\section{Kelemahan Pembelajaran Tematik}

Menurut Abd. Kadir dan Hanun Asrohah (2015: 26) kelemahan yang sangat terlihat dalam pembelajaran tematik antara lain: 
a. Pembelajaran lebih kompleks dan menuntut guru untuk mempersiapkan diri secara lebih supaya dapat melaksanakan dengan baik.

b. Persiapan yang harus dilakukan oleh guru menjadi lebih lama. Guru harus merancang pembelajaran tematik dengan memperhatikan keterkaitan antara berbagai pokok materi tersebar di beberapa mata pelajaran.

c. Penyediaan alat, bahan, sarana, dan prasarana untuk berbagai materi harus lebih lengkap.

\section{METODE PENELITIAN}

\section{A. Tempat dan Waktu Penelitian}

Penelitian ini dilakukan di SD N Kadipiro No. 144 Kelurahan Kadipiro, Kecamatan Banjarsari, Kota Surakarta, Jawa Tengah. Waktu pelaksanaannya ialah selama enam bulan, yaitu dari bulan Januari sampai dengan bulan Juni 2019, pada semester 2, Tahun Pelajaran 2018/2019.

\section{B. Bentuk dan Strategi Penelitian}

Penelitian ini menggunakan metode kualitatif untuk memahami kejadian berupa proses berlangsungnya pembelajaran tematik pada peserta didik Kelas IV, Tema 8 "Daerah Tempat Tinggalku", Subtema 3 di Pembelajaran ke-1 hingga Pembelajaran ke6. Hal tersebut dilakukan untuk menganalisis problematika pembelajaran tematik.

\section{C.Sumber Data}

\section{Data Primer}

Data primer merupakan data yang diperoleh dari gambaran situasi ataupun kondisi yang berhubungan dengan masalah yang dibahas oleh peneliti. Data primer dalam penelitian ini yaitu guru Kelas IV dan peserta didik Kelas IV di SD N Kadipiro No. 144 Surakarta.

2. Data Sekunder

Data sekunder dalam penelitian ini diperoleh dari hasil observasi, wawancara dengan kepala sekolah, dan wali kelas, Kelas IV serta sumber kepustakaan yang berasal dari buku maupun jurnal.

\section{Subjek dan Objek Penelitian}

1. Subjek Penelitian

Subjek penelitian ini adalah peserta didik Kelas IV, dan guru Kelas IV di SD N Kadipiro No. 144 Surakarta.

2. Objek Penelitian

Objek analisis problematika pembelajaran tematik ini adalah problematika pembelajaran tematik peserta didik kelas IV. Adapun jumlah peserta didik Kelas IV di SD N Kadipiro No. 144 Surakarta ialah 32 peserta didik, yang terdiri dari 17 peserta didik lakilaki, dan 15 peserta didik perempuan.

\section{E. Teknik Pengumpulan Data}

Sebuah data yang akurat memerlukan teknik pengumpulan data yang relevan dengan pokok penelitian. Untuk itu, peneliti menggunakan teknik pengumpulan data observasi (pengamatan), wawancara semi terstruktur, dan angket terbuka.

\section{F. Keabsahan Data}

Penelitian ini menggunakan trianggulasi sumber dan trianggulasi metode. Menurut Djam'an Satori dan Aan Komariah (2017: 170) Trianggulasi sumber merupakan cara mengecek data melalui sumber data yang terdapat di lapangan. Sumber pada penelitian ini yaitu kepala sekolah, peserta didik, dan guru kelas. Sedangkan trianggulasi metode merupakan pengecekan data melalui cara pengumpulan data yang digunakan. Metode penelitian ini yaitu dokumentasi, wawancara dengan kepala sekolah, observasi dalam kegiatan belajar mengajar peserta didik, dan hasil wawancara dengan empat guru di SD N Kadipiro No. 144 Surakarta.

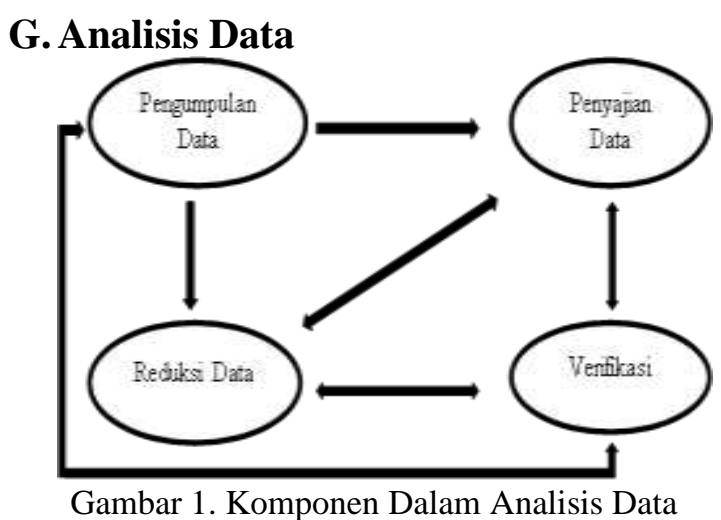

Widya Wacana Vol. 14 Nomor 2, Agustus 2019 


\section{HASIL PENELITIAN DAN \\ PEMBAHASAN}

A. Ranah Kognitif (Pengetahuan)

Muatan IPS dan Bahasa

Indonesia menjadi problematika mayoritas peserta didik yang terdapat pada Tema 8, Subtema 3. Terlihat dari hasil observasi selama pembelajaran tematik yang mengandung muatan tersebut dilaksanakan dan didukung dengan wawancara sekilas dengan peserta didik saat pembelajaran. Pada sebagian peserta didik yang sudah memenuhi KKM, muatan pelajaran yang lain juga sulit dipahami.

Muatan IPS, Subtema 3 terletak di Pembelajaran ke-3 dan Pembelajaran ke-4. Melalui materi mengenai kegiatan ekonomi yang disajikan, wali kelas Kelas IV memperluas materi pekerjaan, sehingga peserta didik diharapkan mampu memahami pekerjaan yang menghasilkan jasa atau barang, kemudian mengidentifikasi serta mengelompokkan pekerjaan yang menghasilkan barang dan menghasilkan jasa. Pekerjaan yang membuat peserta didik kurang benar menjawabnya dan bingung mengelompokkannya ialah pengrajin, tukang, pegawai PLN, chef, penjaga apotek, pegawai pelukis, tukang foto, penulis, pembuat tahu, penjahit, dan arsitek. Salah satu peserta didik yang masih perlu belajar untuk mengelompokkan pekerjaan yang menghasilkan barang dan jasa ialah peserta didik A. Observasi pada pelaksanaan Pembelajaran ke-3 pun menunjukkan bahwa peserta didik D masih belum benar menjawab guru yang menanyakan penjahit termasuk pekerjaan yang menghasilkan barang atau jasa. Jawaban dari peserta didik D ialah menghasilkan jasa.

Pembelajaran ke-4 muatan IPS membahas materi tentang corak kehidupan kegiatan ekonomi dan keberagaman karakteristik individu.

Pada pembelajaran ini peserta didik diminta untuk mengamati penduduk di sekitar tempat tinggalnya. Setelah mengamati, peserta didik diminta mengidentifikasi pekerjaan penduduk yang terdapat di sekitar tempat tinggalnya. Kegiatan pengamatan ini memiliki problematika kurangnya waktu yang dimiliki oleh guru untuk mengamati penelitian setiap peserta didik secara langsung. Akibatnya, terdapat kemungkinan berkurangnya kejujuran peserta didik untuk benarbenar mengamati dan mencari tahu pekerjaan yang terdapat di sekitar tempat tinggalnya. Penyampaian pekerjaan dalam kegiatan ekonomi yang merupakan keberagaman karakteristik individu oleh guru juga masih kurang. Sehingga peserta didik tidak memahami kaitannya dengan baik.

\section{Materi}

keberagaman

karakteristik individu tersebut disajikan ke dalam bentuk bacaan fiksi yang merupakan salah satu bentuk muatan Bahasa Indonesia. Muatan Bahasa Indonesia pada Tema 8 "Daerah Tempat Tinggalku", Subtema 3 terdapat di semua pembelajaran. Kompetensi dasar dari muatan tersebut ialah "Mencermati tokoh-tokoh pada teks fiksi" dan "Menyampaikan hasil identifikasi tokoh-tokoh yang terdapat pada teks fiksi secara lisan, tulis, dan visual". Ketika mencermati tokoh pada bacaan, terdapat peserta didik yang kurang teliti untuk membaca. Hal tersebut mengakibatkan mereka tidak dapat menyebutkan tokoh dengan baik. Problematika lain yang ditemukan pada muatan Bahasa Indonesia dalam cerita fiksi yaitu menentukan konflik dalam cerita. Peserta didik belum mengetahui secara jelas definisi dari konflik. Mereka mengira bahwa konflik itu adalah pertengkaran yang terjadi di kehidupan.

Muatan PPKN yang terdapat pada Pembelajaran ke-3, 4, dan ke-5, juga memberikan problematika kepada lima peserta didik di Kelas IV SD N 
Kadipiro No. 144 Surakarta. Problematika tersebut terdapat pada Pembelajaran ke-5 yang terdapat keberagaman karakteristik Indonesia dengan mempelajari 34 suku provinsi di Indonesia. Kelima peserta didik tersebut belum mampu menghafalkan rumah adat, pakaian adat, tarian daerah, dan bahasa yang dimiliki oleh setiap suku. Hal tersebut menjadikan nilai mereka tidak memenuhi KKM. Sebanyak 56, $25 \%$ peserta didik Kelas IV di SD N Kadipiro No. 144 Surakarta pun mendapatkan hasil yang mepet dari KKM pada muatan PPKN. Problematika yang membuat nilai mereka mepet pun juga ketika menjawab soal mengenai keberagaman karakteristik masyarakat Indonesia pada Pembelajaran ke-5. Selain pembahasan mengenai materi tersebut, peserta didik juga mengalami kesulitan untuk mengidentifikasi keberagaman karakteristik individu yang ada di sekitar rumah mereka. Hal tersebut dikarenakan kurangnya sikap mengenal orang-orang yang menjadi tetangga mereka sendiri.

Muatan berikutnya ialah IPA yang paling disukai peserta didik karena dianggap paling mudah pada Tema 8 "Daerah Tempat Tinggalku". Adapun problematika yang muncul ialah sebesar $15,6 \%$ peserta didik belum memenuhi KKM. Peserta didik kesulitan menyebutkan pengaruh gaya terhadap benda. Mereka harus diberikan umpan terlebih dahulu supaya mengetahui arti dari soal yang meminta peserta didik menyebutkan pengaruh gaya terhadap benda tersebut. Peserta didik G misalnya. Ketika ditanya secara lisan pengaruh gaya terhadap sumur, dirinya gugup dan tidak bisa menjawab. Dia baru bisa menjawab setelah gurunya menanyakan cara mengambil air di dalam sumur.

Berdasarkan hasil penelitian pada ranah kognitif, guru Kelas IV belum sepenuhnya berhasil dalam mengajarkan materi pembelajaran tematik. Hal tersebut disebabkan karena kurangnya kreatifitas guru dalam menggunakan media ketika mengajar. Penggunaan metode penugasan, ceramah, dan diskusi membuat peserta didik bosan untuk belajar di dalam kelas. Oleh karena itu, tingkat pemahaman peserta didik pada pembelajaran tematik masih sebesar 78, $13 \%$.

\section{B. Ranah Afektif (Sikap)}

Berdasarkan hasil observasi dan wawancara dengan wali kelas, karakter yang paling sulit ditanamkan kepada peserta didik ialah percaya diri. Peserta didik Kelas IV tidak berani menjawab pertanyaan guru atau maju ke depan kelas tanpa ditunjuk oleh guru. Dalam hal keaktifan untuk menyampaikan pendapat atau berbicara, mereka masih sangat kurang. Sehingga guru menerapkan urutan absen untuk peserta didik menjawab pertanyaan dari guru atau maju ke depan kelas. Terkadang guru juga menunjuk peserta didik yang gaduh atau terlihat melamun saat pembelajaran berlangsung. Sikap tidak percaya diri peserta didik juga ditunjukkan lirihnya suara mereka ketika menjawab pertanyaan dan membaca di depan kelas. Peserta didik $\mathrm{C}$ mengaku grogi ketika menjawab pertanyaan guru atau maju ke depan kelas, sehingga berpengaruh pada suaranya ketika menyampaikan pendapat atau membaca di depan kelas.

Hasil observasi penulis juga menunjukkan karakter jujur perlu lebih ditanamkan lagi. Sebab, masih terdapat peserta didik yang bertanya temannya dan membuka buku secara sembunyisembunyi ketika ulangan harian berlangsung. Padahal sudah disampaikan oleh wali kelas untuk mandiri dalam mendapatkan nilai. Ketika penulis bertanya kepada peserta didik C kenapa ia membuka buku saat ulangan, ia menjawab takut apabila hasilnya tidak lebih dari KKM, kemudian dimarahi oleh orang tuanya. Sebab ia lupa materi yang sudah ia pelajari.

C. Ranah Psikomotorik (Keterampilan) 
Psikomotorik Tema 8 "Daerah Tempat Tinggalku", Subtema 3, terdapat pada Pembelajaran ke-5 dan Pembelajaran ke-6. Kompetensi dasar dari muatan SBdP dalam subtema ini yaitu "mengetahui gambar dan bentuk tiga dimensi" dan "membuat gambar cerita". Pembelajaran ke-5 mengenalkan peserta didik dengan bentuk tiga dimensi secara lebih lanjut serta membuat sketsa. Dalam materi bentuk tiga dimensi, peserta didik diminta untuk menggambar bentuk tiga dimensi berupa kendi. Kegiatan menggambar tersebut memunculkan problematika kepada guru dan peserta didik. Problematika dari guru ialah mengajarkan konsep kepada peserta didik secara menyeluruh untuk menggambar benda tiga dimensi. Hal tersebut menyebabkan tiga peserta didik mengalami kesulitan untuk menggambar bentuk benda tiga dimensi secara seimbang. Peserta didik B mengaku menggambar kendi itu sulit, sehingga ia harus menghapus gambarnya berkali-kali.

Setelah menggambar kendi, peserta didik diminta untuk membuat sketsa lingkungan tempat tinggal dan rumah mereka sebagai contoh lain dari bentuk benda tiga dimensi. Peserta didik yang sudah selesai membuat sketsa, diminta maju ke depan dengan percaya diri untuk mendeskripsikan gambar mereka di depan kelas. Peserta didik B kebingungan untuk mendeskripsikan sketsa lingkungan tempat tinggalnya di depan kelas. Sebab ia mengira hanya diminta untuk menggambar, tidak mendengarkan perintah gurunya untuk mendeskripsikan gambar di depan kelas ketika sudah selesai. Sehingga ia tidak menyiapkan cerita mengenai gambar sketsa tempat tinggalnya.

Rumah merupakan salah satu bentuk tiga dimensi yang dapat dibuat dengan kayu atau stick ice cream. Oleh karena itu, pembelajaran tiga dimensi pada Pembelajaran ke-5 dilanjutkan dengan membuat rumah adat dari stick ice cream secara berkelompok (satu kelompok ada dua peserta didik). Rumah adat yang dibuat berbeda-beda, tergantung bagian yang diberikan oleh guru secara acak. Keesokan harinya, peserta didik secara berpasangan dengan kelompoknya diminta maju ke depan untuk mendeskripsikan rumah adatnya, meliputi asal daerahnya serta pakaian dan ciri khas dari suku yang memiliki rumah adat tersebut.

Tugas membuat rumah adat dari stick ice cream secara kelompok tersebut menimbulkan beberapa problematika dari peserta didik untuk menempelkan antara stick satu dengan stick yang lainnya agar dapat berdiri dengan tegak. Selain itu, peserta didik kesulitan membuat rumah adat karena bentuknya yang rumit. Sedangkan pada bagian menyiapkan cerita untuk dipresentasikan ke depan kelas mengenai rumah adat ini, peserta didik menemukan problematika untuk menyusun kalimat. Hal tersebut membuat masing-masing kelompok saling menunjuk untuk maju ke depan dan banyak kelompok yang tidak mengerjakan tugas mereka untuk membuat rumah adat tersebut. Untuk itu, guru meminta mereka membuat rumah dari stick ice cream secara individu agar peserta didik belajar membuat karya tersebut secara mandiri.

Peserta didik $\mathrm{G}$ membuat rumah dengan bantuan dari temannya. Ia mengaku tidak bisa membuat sendiri secara keseluruhan. Hal tersebut dikarenakan ia perlu bantuan seseorang untuk memegang stick nya ketika ditempelkan. Tetapi sebelum mendapatkan bantuan dari teman, dirinya sudah mencoba menempelkan sendiri. Sayangnya, percobaannya selama 15 menit belum berhasil. Oleh karena itu, gurunya mengizinkannya untuk dibantu teman sebelahnya.

SBdP pada Pembelajaran ke-6 mengajak peserta didik untuk membuat benda berbentuk tiga dimensi dari 
plastisin. Dalam kompetensi ini banyak peserta didik yang menyukainya. Dengan begitu, banyak peserta didik yang bisa membuat benda berbentuk tiga dimensi dari plastisin dengan senang. Peserta didik F mengaku senang karena ketika membuat benda tiga dimensi dari plastisin bisa sambil bermain. Sayangnya, banyak peserta didik yang membuat benda dengan bentuk yang sama.

Berdasarkan hasil penelitian ranah psikomotor pada pembelajaran

\section{KESIMPULAN DAN SARAN}

Berdasarkan hasil penelitian dan pembahasan, maka dapat ditarik kesimpulan sebagai berikut:

1. Problematika pembelajaran tematik dapat dilihat dari sisi peserta didik maupun guru. Adapun dari peserta didik, problematika tersebut dikelompokkan menjadi tiga ranah, yaitu ranah kognitif, ranah afektif, dan ranah psikomotorik. Sedangkan dari sisi guru ialah dari segi persiapan, sarana prasarana dan penilaian.

2. Problematika yang paling banyak ditemukan dari peserta didik dalam ranah kognitif terletak pada muatan pelajaran IPS, pada materi barang dan jasa yang mengajak peserta didik

\section{B. SARAN}

Berdasarkan kesimpulan, saran dari peneliti ialah sebagai berikut:

1. Bagi Guru

Guru seharusnya lebih menanamkan keyakinan kepada peserta didik untuk memiliki sikap percaya diri terhadap kemampuan yang mereka miliki dengan meminta peserta didik untuk maju ke depan kelas disertai antusias untuk menjawab atau membaca di depan kelas. Dalam ranah kognitif, guru seharusnya melatih peserta didik untuk membuat inti sari bacaan dengan menerapkan $5 \mathrm{~W}+1 \mathrm{H}$ pada bacaan (What, Who, Where, When, Why, dan How). Sedangkan pada ranah psikomotorik, guru seharusnya meminta peserta didik menyalurkan kreatifitas tematik, guru belum berhasil meningkatkan kreativitas dan inovasi peserta didik. Hal tersebut dikarenakan guru jarang memberikan contoh yang konkret ketika mengajarkan dan memberi tugas untuk membuat keterampilan tertentu, baik secara gambar maupun kerajinan tangan. Sehingga peserta didik dalam melaksanakan pembelajaran tematik kebingungan serta sulit mendapatkan pandangan untuk membuat kerajinan tangan.

\section{A. KESIMPULAN}

untuk mengelompokkan dan mengidentifikasi jenis-jenis pekerjaan, serta muatan pelajaran Bahasa Indonesia dalam menentukan penokohan cerita pada bacaan.

3. Pada ranah afektif, guru belum berhasil menanamkan sikap percaya diri kepada peserta didik untuk menyampaikan pendapat dan maju ke depan kelas.

4. Ranah psikomotorik memiliki problematika saat guru meminta peserta didik menggambar benda berbentuk tiga dimensi, mendeskripsikan hasil karyanya secara mandiri, dan meminta peserta didik membuat kesenian dengan bentuk yang sesuai.

mereka dengan memberikan contoh konkret kepada peserta didik.

2. Bagi Sekolah

Sekolah seharusnya menyediakan sarana prasarana yang lengkap. Dengan adanya kelengkapan tersebut, pelaksanaan pembelajaran menjadi lebih menyenangkan dan menciptakan pengalaman yang baru. Sehingga peserta didik mampu menguasai materi yang diajarkan.

3. Bagi Penelitian Selanjutnya

Peneliti selanjutnya yang menganalisis problematika pembelajaran tematik diharapkan dapat meneliti pelaksanaan pembelajaran tematik pada tema-tema yang lain, baik di Kelas IV maupun di Kelas lain pada sekolah lain. Hal tersebut supaya dapat membantu 
meningkatkan kualitas pembelajaran pada pendidikan.

\section{DAFTAR PUSTAKA}

Abd. Kadirdan Hanun Asrohah. 2015. Pembelajaran Tematik. Jakarta: PT. Rajagrafindo Persada

Djam'an Satori dan Aan Komariah. 2017. Metodologi Penelitian Kualitatif. Bandung: CV. Alfabeta

Rusman. 2016. Model-Model Pembelajaran Mengembangkan
Profesionalisme Guru. Jakarta: PT. Rajagrafindo Persada

Sa'dun Akbar, Iffah Qurrotul A'yun, Febrianti Yuli Satriani, Wahyu Widodo, Rakyan Paranimmita S.K, Dina Ferisa. .2017. Implementasi Pembelajaran Tematik di Sekolah Dasar. Bandung. PT. Remaja Rosdakarya

Zainal Aqib. 2010. Profesionalisme Guru Dalam Pembelajaran. Surabaya: Insan Cendikia 